\title{
PUSIAUSVYROS IR KOORDINACIJOS PRATIMU巳 POVEIKIS SERGANČIŲJŲ BIPOLINIU SINDROMU PSICHOEMOCINEI BŪKLEI
}

\author{
Ligita Aučynienė, Romutė Jonušaitė, Inga Muntianaitė, Ieva Eglè Jamontaitė \\ Vilniaus universiteto Medicinos fakulteto Sveikatos mokslu institutas
}

Raktažodžiai: bipolinis sindromas, pusiausvyra, koordinacija, kineziterapija.

\section{Santrauka}

Tyrimo tikslas - įvertinti pusiausvyros ir koordinacijos pratimų poveikị, asmenų sergančių bipoliniu sindromu, psihoemocinei būklei.

Tiriamieji ir tyrimo metodai. 40 pacientų, kuriems pagal TKL - 10-AM kriterijus diagnozuotas bipolinis sindromas. Amžiaus vidurkis - 37,3 $\pm 16,6$ metų. Atsitiktinès atrankos būdu tiriamieji susikirstyti ị dvi grupes: tiriamają ir kontrolinę. Tiriamosios grupès pacientams KT procedūrų metu be raumenis stiprinančių, sąnarių paslankumą gerinančių pratimų buvo taikomi judesių koordinaciją bei pusiausvyrą lavinantys pratimai. Kontrolinei grupei buvo taikoma iprasta KT procedūra, skiriant raumenis stiprinančius, sąnarių paslankumą gerinančius bei bendralavinamuosius pratimus. Tyrimo metu pacientų statinei ir dinaminei pusiausvyrai vertinti taikytas Flamingo testas bei Schmitz (1988) pusiausvyros mėginiai, viršutinių galūnių judesių koordinacijai tirti pasirinktas „, 9 skylučių kaištukų lentos testas“ bei Schmitz (1988) pusiausvyros nereikalaujantys koordinacijos mėginiai; psichoemocinei būklei ịvertinti - Beko depresijos skalè.

Rezultatai. Analizuojant tiriamosios grupès Beko depresijos skalès rodiklius kineziterapijos ciklo eigoje, jie vidutiniškai sumažejo $8,8 \pm 6,1$ balo $(\mathrm{p}=0,04)$. Kontrolinèje grupejje depresijos skalès rodikliai statistiškai reikšmingai nepakito $(\mathrm{p}=0,4)$. Vertinant respondentų pusiausvyrą pagal Schmitz, tiriamosios grupès atliekamų mėginių suma KT ciklo eigoje vidutiniškai padidejo $4,3 \pm 6,45$ balais $(p=0,00)$, kontrolinès - $3 \pm 9,1$ balais $(\mathrm{p}=0,01)$. Flamingo testo méginiu skaičius KT ciklo eigoje tiriamojoje grupejje vidutiniškai sumažejjo $1,7 \pm 2,3$ karto $(\mathrm{p}=0,01)$, kontrolinèje $-0,9 \pm 4,4(\mathrm{p}=0,00)$. Vertinant Schmitz pusiausvyros nereikalaujančius koordinacijos mėginius, jų suma KT ciklo eigoje padidejo $1,3 \pm 6,6$ balais $(\mathrm{p}=0,00)$, kontrolinès $-0,6 \pm 8,9$ balais $(\mathrm{p}=0,01)$. Tiriamosios grupès „9 skylučių lentos testo" rezultatai atliekant testą kaire ir dešine ranka, KT ciklo eigoje pakito statistiškai reikšmingai $(p=0,00 ; p=0,00)$. Kontrolinejje grupeje statistiškai reikšmingas skirtumas stebimas tik atliekant testą kaire ranka $(\mathrm{p}=0,04)$.

Išvada. Koordinacijos ir pusiausvyros pratimai, ittraukti į bendrają KT programą, ne tik pagerino tiriamujų pusiausvyrą ir koordinaciją $(\mathrm{p}<0,05)$, bet ir psichoemocinę būseną, kurią parodo Beko depresijos skalès rodiklių sumos reikšmingas sumažèjimas $(\mathrm{p}=0,04)$.

\section{Ivadas}

Psichikos sveikata - viena iš svarbiausių ir bene dažniausiai pažeidžiamų vertybių šiuolaikinèje visuomenèje. [1] Vykstant demokratinių vertybių kaitai ir plètrai, turime atsižvelgti i žmogaus psichikos sveikatos ypatumus, kuriuos lemia socialiniai, kultūriniai bei indvidualūs veiksniai. Tarp labiausiai paplitusių psichikos sveikatos sutrikimų pasaulyje, depresija, pasireiškianti daugeliu emocinių, psichologinių, elgesio ir somatinių simptomų, beveik siekia epideminị lygị. Remiantis naujausiais PSO duomenimis, 2005-2015 m. sergančiųjų depresija skaičius išaugo 18 proc. ir daugiau kaip 300 milijonų žmonių visame pasaulyje serga depresija. Tai dažnas psichikos sveikatos sutrikimas Lietuvoje ir Vakarų pasaulio šalyse, kuris pagal tiketinas tendencijas dar labiau plis per ateinančius 20 metų [2]. Depresija atsiranda dèl sudètingos socialinių, psichologinių ir biologinių veiksnių sąveikos. Depresija gali sukelti disfunkciją, pabloginti gyvenimo kokybę, paveikdama psichologinę, emocinę ir fizinę būklę [3].

Gausėjančios išlaidos, susijusios su depresijos ir nerimo gydymu, yra didžiule visuomenès sveikatos problema išsivysčiusiose ir besivystančiose pasaulio šalyse. Be tradicinio gydymo psichoterapija ir medikamentais, vis didesnis dé- 
mesys skiriamas depresijos gydymui fiziniu aktyvumu [4]. Nacionalinis sveikatos ir klinikinès kompetencijos institutas 2006 m. ịtrauké fizinès veiklos rekomendacijas ị bipolinio sindromo gydymo gaires kaip prevencinę priemonę, siekiant sumažinti sergamumą psichikos sveikatos sutrikimais [5]. Nagrinejjant psichoemocinių sutrikimų poveikį fizinei būklei, buvo pastebėtas vienas iš unikalių depresijos simptomu požymių - psichomotorinis sulètėimas (angl. Psychomotor retardation), paveikiantis stambiają ir smulkiają motoriką, koordinaciją bei pusiausvyrą [6], pasireiškiantis nekoordinuotais, sulètejusiais galūnių judesiais, sutrikusia laikysena, sulètejusia, neartikliuota kalba. Tyrimai rodo, jog tikslingai taikomas fizinis aktyvumas - daug žadantis gydymo būdas pacientams, sergantiems depresija. Fizinis aktyvumas mažina depresinius epizodus, gerina emocinę ir fizinę būklę, mažina psichomotorinio suletejjimo simptomus [7].

Tyrimo tikslas - iqvertinti pusiausvyros ir koordinacijos pratimų poveikị asmenų, sergančių bipoliniu sindromu, psichoemocinei būklei.

\section{Tyrimo organizavimas ir metodologija}

Tyrime dalyvavo 40 bipoliniu sindromu sergančių bei stacionare besigydančių pacientų. Visi tiriamieji - darbingo amžiaus žmonės, amžiaus vidurkis $37,3 \pm 16,6$ metų. Jauniausias tiriamasis buvo 18 , vyriausias - 62 metų. Atstiktinès atrankos būdu tiriamieji susikirstyti ị dvi grupes: tiriamają $(\mathrm{n}=20)$ ir kontrolinę $(\mathrm{n}=20)$. Tiriamosios grupés pacientams kineziterapijos (toliau - KT) procedūrų metu be raumenis stiprinančių, sąnarių paslankumą gerinančių pratimų buvo taikomi judesių koordinaciją bei pusiausvyrą lavinantys pratimai. Kontrolinei grupei buvo taikoma ịprastinè KT procedūra, skiriant raumenis stiprinančius, sąnarių paslankumą gerinančius bei bendralavinamuosius pratimus. Procedūrų trukmè abiejų grupių pacientams buvo po $60 \mathrm{~min}$., vieną kartą per dieną, penkis kartus per savaitę (iš viso $15 \mathrm{KT}$

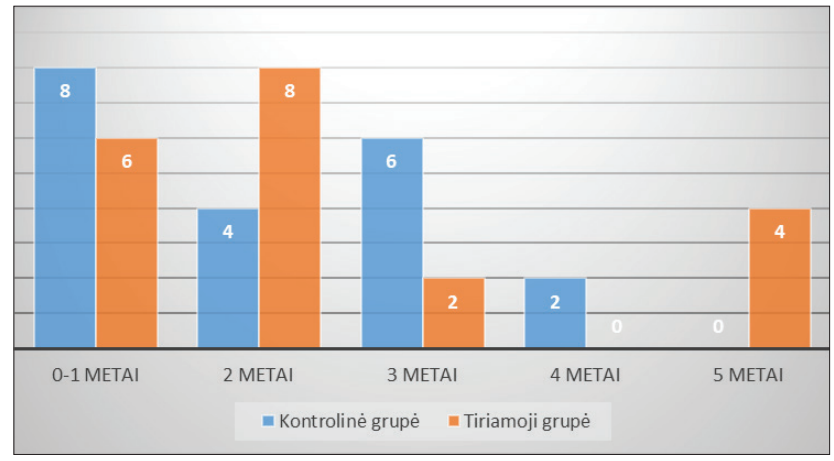

1 pav. Tiriamujų (vnt.) pasiskirstymas pagal ligos trukmę tiriamojoje ir kontrolinejje grupèse procedrūrų). Be KT užsièmimų visiems pacientams buvo taikomas medikamentinis gydymas, psichoterapija bei psichoedukacija. Respondentai buvo funkciškai savarankiški (Funkcinio nepriklausomumo testo (FNT) rezultatas $>80$ balų) ir neturejo gretutinių susirgimų, turinčių poveikị judesių koordinacijai ir pusiausvyrai (pvz., Parkinsono liga).

Tyrimo metu statinei ir dinaminei pusiausvyrai vertinti taikytas Flamingo testas bei Schmitz (1988) pusiausvyros mèginiai. Tiriant statinę pusiausvyrą pagal Flamingo testą, respondentai buvo vertinami pagal mèginių, kuriais buvo bandoma išlaikyti pusiausvyrą stovint ant buomelio 1 minutę, skaičių. Kuo mažesnis mèginių skaičius, tuo geriau vertinama paciento pusiausvyra. Atliekant pusiausvyros mėginius pagal Schmitz, tiriamieji buvo vertinami pagal surinktų balu skaičių. Maksimali šių mėginių balų suma - 56. Kuo didesnè surinktų balų suma, tuo geriau vertinama tiriamojo pusiausvyra. Viršutinių galūnių judesių koordinacija buvo tiriama taikant „9 skylučių kaištukų lentos testą“ bei Schmitz (1988) pusiausvyros nereikalaujančius koordinacijos mėginius. „9 skylučių kaištukų lentos testo" metu tiriamieji atliko testą kaire ir dešine rankomis. Rezultatas buvo užrašomas ir vertinamas pagal testo atlikimo laiką (sekundèmis).

Vertinant judesių koordinaciją pagal Schmitz (1988), tiriamieji atliko du pusiauvyros nereikalaujančius mėginius, kurių maksimali vertinimo suma -8 balai. Psichoemocinei būklei vertinti pasirinkta Beko depresijos skalè (toliau BDS), apimanti 21 depresijos simptomų vertinimo rodikli. Depresijos lygmuo vertinamas pagal surinktų balų skaičių - kuo jis mažesnis, tuo psichoemociné būsena geresnè.

\section{Rezultatai}

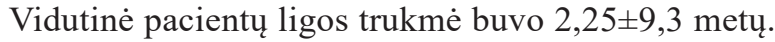
Ilgiausiai sergančių ligos trukmė buvo penkeri, trumpiausiai - vieneri metai (1 pav.). Vidutinè kontrolinès grupès

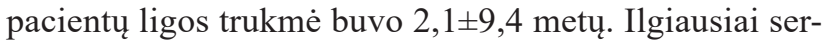
gančių pacientų ligos trukmė kontrolinėje grupejje buvo 4 ,

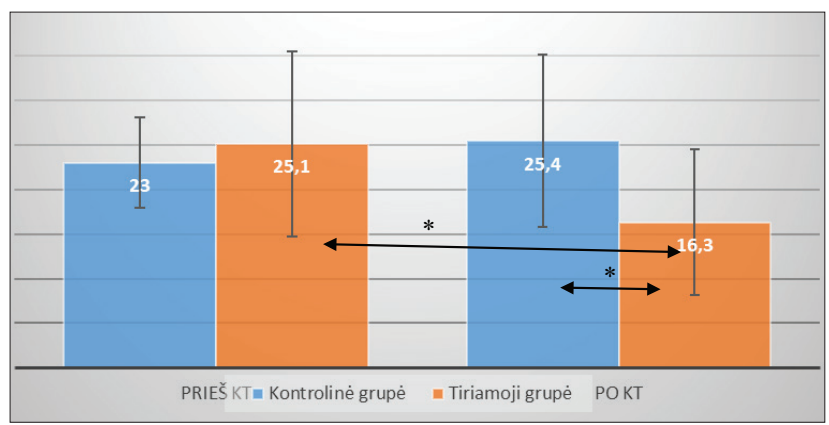

2 pav. Beko depresijos skalès vidurkis (balais) prieš ir po KT ciklo tiriamojoje ir kontrolinèje grupèse

* Statistiškai reikšmingas skirtumas $(p<0,05)$ 
o trumpiausiai - 1 metai. Tuo tarpu tiriamojoje grupeje vidutinè pacientų ligos trukmè buvo 2,4 $\pm 9,3$ metų. Ilgiausiai sergančių pacientų ligos trukmè tiriamojoje grupejje buvo 5 , o trumpiausiai - 1 metai.

Vertinat Beko depresijos skalès rodiklius, tiriamojoje grupeje pastebėta, jog surinktų balų skaičius po kineziterpijos ciklo vidutiniškai sumažèjo $8,8 \pm 6,1$ balo $(\mathrm{p}=0,04)$. Kontrolinèje grupeje Beko skalès balų vidurkis KT ciklo pabaigoje pakilo vidutiniškai $2,4 \pm 9,3$ balo $(\mathrm{p}=0,4)$. Palyginus Beko depresijos skalès balų vidurkị tarp tiriamosios ir kontrolinès grupių, po KT užsièmimų stebimas statistiškai reikšmingas skirtumas $(\mathrm{p}=0,03)(2 \mathrm{pav}$.$) .$

Shmitz pusiauvyros mèginių balų vidurkis tiriamojoje grupejje po KT užsièmimų vidutiniškai padidejo 4,3 3 6,45 balais $(\mathrm{p}=0,00)$. Kontrolinèje grupeje surinktų balų vidurkis vidutiniškai padidejo $3 \pm 9,1$ balo ( $\mathrm{p}=0,01)$. Palyginus kontrolinès ir tiriamosios grupès vidurkius, tarpusavyje statistiškai reikšmingas skirtumas buvo nustatytas po KT $(\mathrm{p}=0,01)(3$ pav.).

Po fizinių pratimų ciklo tiriamųjų grupèje Flamingo

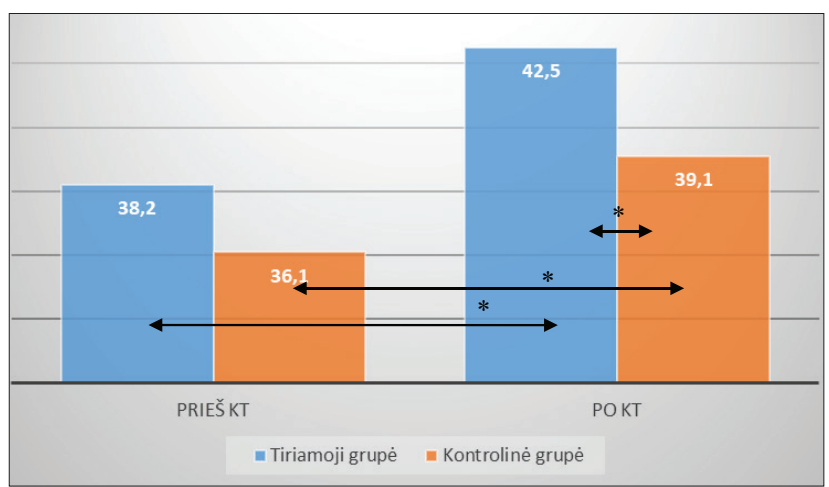

3 pav. Schmitz pusiausvyros mėginių vidurkis (balais) prieš ir po KT ciklo tiriamojoje ir kontrolineje grupèse *Statistiškai reikšmingas skirtumas $(p<0,05)$

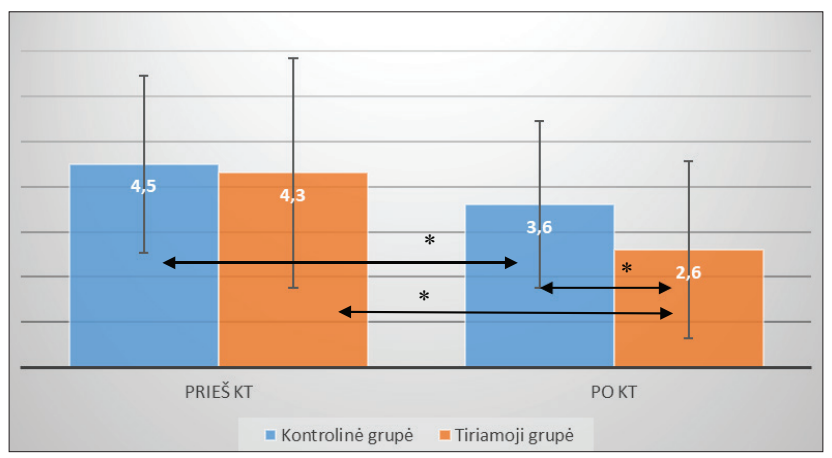

4 pav. Flamingo testo mėginių vidurkis (kartais) prieš ir po KT ciklo tiriamojoje ir kontrolinèje grupèse *Statistiškai reikšmingas skirtumas $(p<0,05)$

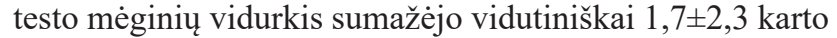
$(\mathrm{p}=0,01)$. Kontrolinejje grupeje testo mėginių vidurkis sumažėjo vidutiniškai $0,9 \pm 4,4$ karto $(\mathrm{p}=0,00)$ (4 pav.). Palyginus kontrolinès ir tiriamosios grupès vidurkius, tarpusavyje statistiškai reikšmingas skirtumas buvo nustatytas po KT $(\mathrm{p}=0,01)$.

Ivertinus tiriamosios grupès Shmitz koordinacijos mèginių rezultatus, jie padidejo vidutiniškai 1,3 $\pm 6,6$ balo $(p=0,00)$. Kontrolinèje grupeje koordinacijos mėginių rezultatų vidurkis padidejo $0,6 \pm 8,9$ balo $(p=0,01)$. Palyginus kontrolinès ir tiriamosios grupès vidurkius, tarpusavyje statistiškai reikšmingas skirtumas buvo nustatytas po KT užsièmimų $(\mathrm{p}<0,05)(5$ pav.).

Išanalizavus kaire ranka atlikto „9 skylučiu lentos testo“ rezultatus pastebeta, jog po KT ciklo tiriamosios grupès testo laikas pagerejjo $1,49 \pm 8,8$ sekundès $(\mathrm{p}=0,00)$. Po KT užsièmimų kontrolinės grupès rezultatas atliekant testą kaire ranka pagerejo $0,37 \pm 10,3$ sekundès $(\mathrm{p}=0,04)$. Stebint tiriamosios grupès vidutinį testo atlikimo laiką dešine ranka, po KT užsiemimų ciklo jis pagerèjo $2,12 \pm 5,45$ sekundès $(\mathrm{p}=0,00)$.

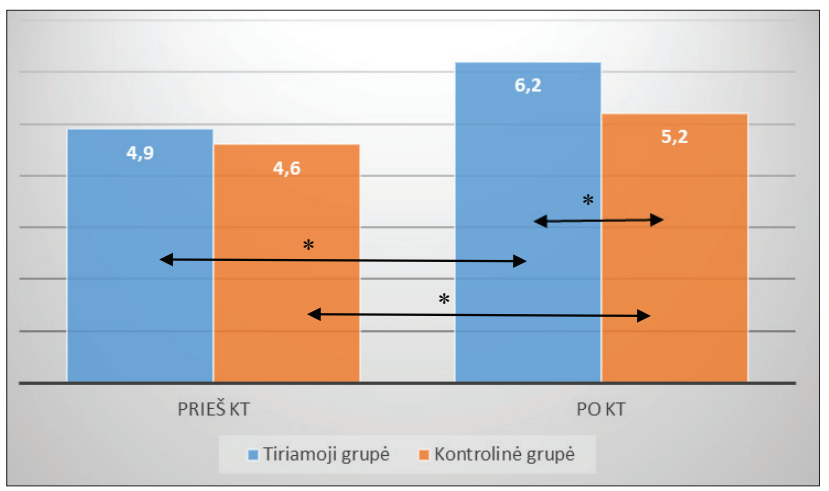

5 pav. Schmitz koordinacijos mėginių vidurkis (balais) prieš ir po KT ciklo tiriamojoje ir kontrolinėje grupèse

*Statistiškai reikšmingas skirtumas $(p<0,05)$

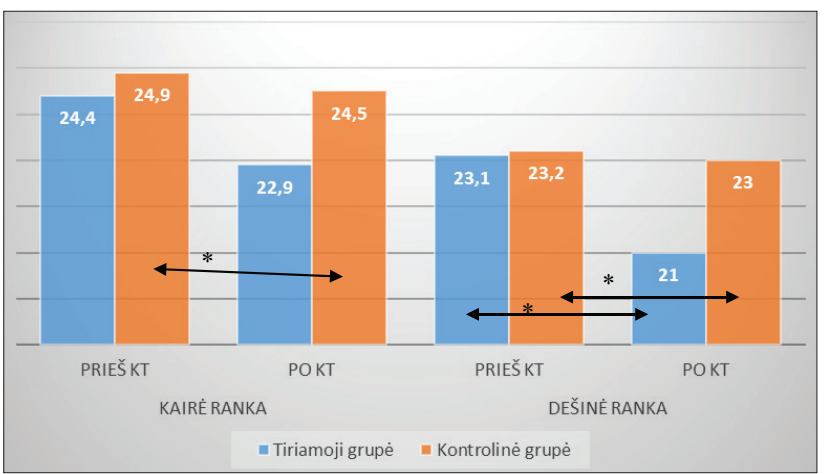

6 pav. „9 skylučių kaištukų lentos testo“ vidutinis atlikimo laikas (s) prieš ir po KT ciklo tiriamojoje ir kontrolinejje grupèse *Statistiškai reikšmingas skirtumas $(p<0,05)$ 
Palyginus kontrolinès grupès vidutinị testo atlikimo laiką dešine ranka prieš ir po KT, statistiškai reikšmingas skirtumas nebuvo nustatytas $(\mathrm{p}=0,53)$.

Palyginus testo rezultatus tarp tiriamosios ir kontrolinès grupès, atliktus dešine ir kaire ranka tarp grupių prieš ir po KT užsièmimų, statistiškai reikšmingas ryšys nebuvo nustatytas $(p=0,24 ; p=0,20 ; p=0,21 ; p=0,4) \quad(6$ pav. $)$.

\section{Rezultatų aptarimas}

İvertinus tyrimo duomenis, buvo nustatytas teigiamas judesių koordinaciją bei pusiausvyrą lavinančių fizinių pratimų poveikis, sergant bipoliniu sindromu. Palyginus psichoemocinès būklès rodiklius grupèje, kurioje buvo taikomi specialūs pratimai judesių koordinacijai ir pusiausvyrai, stebimas statistiškai reikšmingas depresijos simptomų pagerejimas. Šios išvados atitinka L.Sylvia ir bendraautorių atlikto tyrimo rezultatus [7], kurio metu taip pat buvo nustatyta, kad fiziniai pratimai mažina depresinių, manijos ar mišrių epizodų apraiškas. Analizuojant pusiausvyros mėginių vidutinị surinktų balų skaičių grupėse ir tarp grupių prieš ir po KT užsièmimų kurso, buvo pastebèti teigiami balų pokyčiai. Ir kontrolinejje, ir tiriamojoje grupèse, o taip pat ir tarp grupių nustatytas statistiškai reikšmingas balų pokytis. Kontrolinès grupès rezultatų pokytis atkreipia dèmesį bei atitinka J. Seco ir bendraautorių tyrimo duomenis [8], kad net ir nespecifinė KT programa lavina bei gerina pacientu pusiausvyrą. Šie rezultatai, grindžiantys teigiamą pusiausvyrą ir koordinaciją gerinančių pratimų poveikị, sutampa su Belgijos ir Didžiosios Britanijos mokslininkų tyrimo [9] duomenimis, kai buvo analizuojamas ištvermès lavinimo pratimų poveikis segantiesiems bipoliniu sindromu.

Atlikto tyrimo duomenimis, KT turètų būti viena pagrindinių kompleksinio gydymo priemonių bipoliniu sindromu sergančių asmenų reabilitacijos procese, siekiant pagerinti jų fizinius parametrus - koordinaciją, pusiausvyrą, raumenų jègą bei sąnarių paslankumą, tuo pat metu skatinant palankesnę psichoemocinę būklę.

\section{Išvada}

Koordinacijos ir pusiausvyros pratimai, itraukti ị bendrają KT programą, pagerino ne tik tiriamųų pusiausvyrą ir koordinaciją $(\mathrm{p}<0,05)$, bet ir psichoemocinę būseną, kurią parodo Beko depresijos skalès rodiklių sumos reikšmingas sumažejimas $(\mathrm{p}=0,04)$.

\section{Literatūra}

1. Hoyle S, Elliott L, Comer L. Available screening tools for adults suffering from bipolar affective disorder in primary care: An integrative literature review. J Am Assoc Nurse Pract 2015;27(5):280-9. https://doi.org/10.1002/2327-6924.12214

2. Knapen J, Coppens E, Vancampfort D, Minquet P, Schueuremans A, de Herdt A, et al. Study on the association between severity/ recovery of depression and severity/recovery of gross motor retardation. Int J Psychosoc Rehabil 2011;16(2):12-21.

3. Probst M. Physiotherapy and mental health. Clin Phys Ther 2017. https://doi.org/10.5772/67595

4. Vancampfort D, Stubbs B, Sienaert P, Wyckaert S, De Hert M, Soundy A, et al. A comparison of physical fitness in patients with bipolar disorder, schizophrenia and healthy controls. Disabil Rehabil 2016;38(20):2047-51.

https://doi.org/10.3109/09638288.2015.1114037

5. Melo MCA, Daher EDF, Albuquerque SGC, De Bruin VMS. Exercise in bipolar patients: a systematic review. J Affect Disord 2016;198:32-8. http://repositorio.ufc.br/bitstream/ riufc/20172/1/2016_art_mcamelo.pdf https://doi.org/10.1016/j.jad.2016.03.004

6. Giboin LS, Gruber M, Kramer A. Task-specificity of balance training. Hum Mov Sci 2015;44:22-31.

https://doi.org/10.1016/j.humov.2015.08.012

7. Sylvia LG, Friedman ES, Kocsis JH, Bernstein EE, Brody BD, Kinrys G, et al. Association of exercise with quality of life and mood symptoms in a comparative effectiveness study of bipolar disorder. J Affect Disord 2013;1-6.

https://doi.org/10.1016/j.jad.2013.07.031

8. Seco J, Abecia LC, Echevarría E, Barbero I, Torres-Unda J, Rodriguez $\mathrm{V}$, et al. A long-term physical activity training program increases strength and flexibility, and improves balance in older adults. Rehabil Nurs 2013;38(1):37-47.

https://doi.org/10.1002/rnj.64

9. Vancampfort D, Sienaert P, Wyckaert S, De Hert M, Stubbs B, Soundy A, et al. Health-related physical fitness in patients with bipolar disorder vs. healthy controls: an exploratory study. J Affect Disord 2015;177:22-7.

https://doi.org/10.1016/j.jad.2014.12.058

\section{THE IMPACT OF BALANCE AND COORDINATION EXERCISES ON PERSONAL PSYCHOEMOTIONAL STATUS FOR PATIENTS WITH BIPOLAR DISORDER}

\section{Aučynienė, R. Jonušaitė, I. Muntianaitè, I.E. Jamontaitė}

Keywords: bipolar disorder, balance, motor coordination, physiotherapy.

Summary

The aim of research work: to evaluate the impact of balance and coordination exercises on personal psychoemotional status for patients with bipolar disorder. Materials and methods: The total of 40 patients participated in the study and the average age of research subjects was $37,3 \pm 16,6$. The subject were divided into 2 groups: study group and control group. In the study group, in addition to the muscles strengthening and joint mobility exercises, movement coordination and balance exercises were used during physiotherapy course.The control group did usual physiotherapy exerci- 
ses for muscles strengthening and joint mobility. During the research, Beck's depression scale was used to evaluate the change of patients' psychoemotional status. The static and dynamic balance of the patients was evaluated by using the flamingo test as well as the Schmitz (1988) examination of balance and coordination. The 9-HPT and the SCHMITZ examination of balance and coordination were used to determine the motor coordination of the participants. The software "The R Project of Statistical Computing" as well as „Microsoft Excel 2016“" were used to analyse the gathered data. Results and conclusions: after the trial Beck's Depression scale results of study group significaly diminished $(p=0,04)$. Evaluating the balance of the respondents according to Schmitz (1988) the amount of samples performed by the study and control groups increased statistically significant $(p=0,00 ; p=0,01)$ in the course of physiotherapy. The mean number of Flaming test samples decreased statistically significant in study and control goup too $(p<0,05)$. The results of 9-HPT in a study group showed statistically significant change in the left and right hand during the physiotherapy $(p=0,00 ; p=0,00)$. In the control group a statistically significant difference was observed only in the left hand test $(p=0,04)$.

Correspondence to: ligita.aucyniene@mf.vu.lt

Gauta 2020-01-23 